
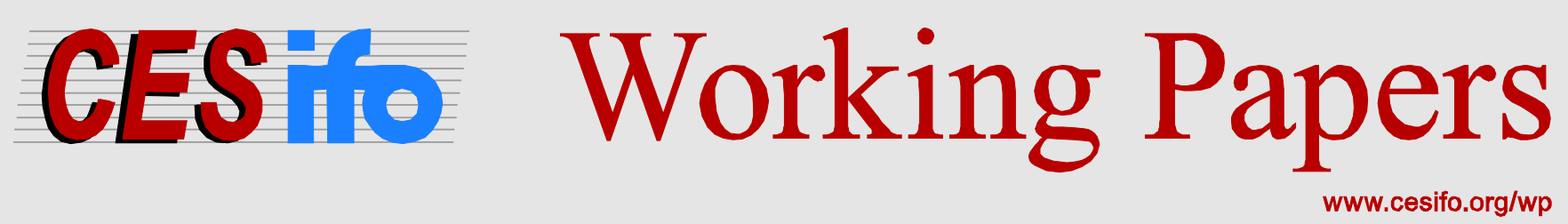

\title{
Probable Oil and Gas Reserves and Shareholder Returns: The Impact of Shale Gas
}

\author{
Bård Misund \\ Petter Osmundsen
}

\author{
CESIFO WORKING PAPER NO. 5687 \\ CATEGORY 10: ENERGY AND ClIMATE ECONOMICS \\ DECEMBER 2015
}
An electronic version of the paper may be downloaded
- from the SSRN website:
- from the RePEc website:
- from the CESifo website:
www.SSRN.com
Www.RePEc.org
www.CESifo-group.org/wp




\title{
Probable Oil and Gas Reserves and Shareholder Returns: The Impact of Shale Gas
}

\begin{abstract}
Oil and gas reserves are the most important assets of oil and gas companies. A source of confusion for investors in oil companies is that reserves quantities and values are uncertain estimates. Reserves are typically classified according to probabilities of recovery from underground reservoirs. All U.S. listed companies have to disclose proved reserves but not probable reserves, thus leaving out potentially important information for investors and financial analysts. This study addresses the impact on market valuation of various classifications of reserves amounts. Using a data sample of 94 companies that do disclose information on probable reserves, we compare the relation between three classifications of reserves and oil company returns. While we find that information on probable reserves do not have an impact on stock returns measured over the entire time period, this is not the case since 2009, coinciding with the onset of the shale gas revolution.
\end{abstract}

JEL-Codes: Q330, Q350, G120.

Keywords: oil and gas reserves, probably reserves, value relevance, accounting figures.

\author{
Bård Misund* \\ University of Stavanger \\ Business School \\ Norway-4036 Stavanger \\ bard.misund@uis.no
}

Petter Osmundsen

Department of Industrial Economics

University of Stavanger

Norway - 4036 Stavanger

petter.osmundsen@uis.no

*corresponding author 


\section{INTRODUCTION}

This paper investigates the relationship between oil and gas reserves and market valuation of oil and gas companies. This is a topic that concerns both investors and analysts. Financial markets can react considerably to substantial changes in oil\&gas companies' reserves. For instance, the discovery of the large Johan Sverdrup field on the Norwegian continental shelf in 2011 led to a 30\% appreciation in Lundin's share price on the day it was announced. Recently, Scholtens and Wagenaar (2011), writing in this journal, find that the revisions of energy reserves significantly impact market values of oil and gas firms.

Although oil and gas reserves are the most important assets for oil \& gas companies, it can be quite challenging for analysts and investors to value the reserves that the companies disclose, the so-called booked reserves. As Osmundsen (2010) points out, the information value of booked reserves (proved reserves) suffers from a number of weaknesses. First, reserves are recognized as a function of average oil and gas price levels during the year. ${ }^{1}$ Second, booked reserves are affected by contractual issues. ${ }^{2}$ Finally, the most commonly referred to type of reserves, namely proved reserves, do not contain complete information on the future growth of the company since the proved

\footnotetext{
1 Under the Financial Accounting Standards Board's (FASB) Statement of Financial Accounting Standards (SFAS) No. 69 (FASB, 1982) the amount of reserves was estimated using oil and gas price at the fiscal year-end, while under the current rules of FASB Accounting Standards Codification Topic 932 (FASB , 2010) the annual average of the monthly average oil and gas prices are used.

2 see also Bindemann (1999) and Kretzschmar et al. (2007) for a discussion on the impact of production sharing agreements on accounting disclosures.
} 
reserves concept excludes less mature reserves. The society of petroleum engineers (SPE, 2011) classifies reserves into three groups based on the uncertainty associated with their recoverability; proved, probable and possible oil and gas reserves. ${ }^{3,4}$ While oil companies calculate internal estimates for all three reserves types, they are only required to disclose one of these, proved reserves, to the financial markets. Thus, vital information relating to oil and gas assets, which investors and financial analysts require to forecast future cash flows, are not disclosed to the market place. The result is a systematic understatement of the true resource base for oil companies. However, in some countries, such as Canada, disclosures of proved and probable reserves are mandatory (CSA 2002a, 2002b). Moreover, the legislation also permit the disclosure of contingent reserves. In 2009/2010 the SEC and FASB updated U.S. disclosure rules allowing for disclosure of less mature reserves (SEC, 2009; FASB, 2009, 2010). Furthermore, several private consultancies such as Wood Mackenzie (www.woodmac.com) gather information on oil and gas fields for oil\&gas companies and provide their own estimate of reserves, including reserve categorizations other than proved reserves. Hence, information on probable reserves is available to investors for a fee, which suggests that market valuations of oil and gas companies might be affected by information on probable reserves held by a part of the investor community. However, our knowledge of the impact of less mature reserves on market valuation is limited. Studies on the impact of

\footnotetext{
${ }^{3}$ SPE combines the reserves into 1P (proved), 2P (proved plus probable) and 3P (proved plus probable plus possible) and define probabilities of $90 \%, 50 \%$ and $10 \%$ of final recovered reserves exceeding the $1 \mathrm{P}, 2 \mathrm{P}$ and $3 \mathrm{P}$ amounts, respectively.
} 
changes in reserves on shareholder returns use either proved reserves amounts (Clinch and Magliolo, 1992; Spear, 1994; Boyer and Filion, 2007; Misund et al., 2008; Misund, 2015) or proved reserves values (Doran et al., 1988; Teall, 1992; Alciatore, 1993; Spear, 1996; Bryant 2003). Very few studies focus on the relative importance of different types of reserves classifications or reserve maturity. The aim of our study is to fill this knowledge gap and examine the impact of changes in different types of reserves classifications on oil company valuation. Althought this topic has not been addressed rigorously in the academic literature, circumstantial evidence suggests that investors do evaluate probable and proved reserves differently. In 2004, the oil major Royal Dutch Shell disclosed a re-classification of $28 \%$ of their oil\&gas reserves, from proved to probable reserves, an announcement which had a significant negative impact on their share price.

To test the research question of how changes in different types of oil and gas reserves relates to returns to shareholders, we employ Ohlson's (1995) theoretical model employed in the multifactor framework of Sadorsky (2001) and Boyer and Filion (2007). We collect three types of reserves classifications which are associated with different probabilities of recoverability; proved developed, proved undeveloped and probable. Proved developed reserves are the most mature and are associated with the highest probability of recovering the underground reserves. On the other hand, probable reserves are associated with the lowest recoverability probability. Although recent updates in U.S. regulation allows U.S. listed oil and gas firms to disclose probably 
reserves (SEC 2008; FASB 2010), few actually do. We have therefore collected data for non-U.S. firms. Our sample consists of 94 Canadian and International oil companies, for the years 1993-2013 (455 firm years).

We address an additional research questions. Recently, Misund (2015) found that the relationship between returns and proved reserves varied across energy type (gas versus oil), and that there had been a structural shift post-2008, coinciding with the onset of the Shale gas revolution in North America. The Shale gas revolution is by many commentators considered a game changer. We examine how this event has affected the relative impact of different reserves classifications on returns. The expectation is that only gas reserves have changed their impact on total shareholder returns since the Shale gas revolution resulted in a sustained lower level of natural gas prices in North America.

We find a significant positive relation between changes in proved developed reserves and oil company returns. The evidence for less mature reserves, however, is unconvincing. Proved undeveloped reserves are only significant at the $10 \%$ level, while we cannot uncover a significant association between oil company returns and probable reserves. This suggests that investors view changes in less mature oil and reserves as uncertain. The picture seems to be different when considering structural events such as the Shale gas revolution. From 1992 to 2013, changes in proved gas reserves were not significantly associated with returns. However, changes in proved undeveloped reserves had a negative impact on valuation, while probable gas reserves were positively 
associated with returns. Moreover, the results suggest that the positive impact of probable gas reserves on returns only appears after the shale gas revolution.

This findings in our paper improves our understanding of how different types of reserves impact oil company returns. In particular, we are able to identify the differential impact of different reserves classifications, and between oil and gas reserves. Moreover, we address whether an important event in the industry, such as the shale gas revolution, has led to a structural shift in the relationship. Furthermore, we base our empirical models on a theoretical model which allows us to include profitability and other value relevant information such as reserves. This approach differs from other studies such as Boyer and Filion (2007).

The remainder of the paper is organized as follows. The next section provides background information on oil and gas reserves in terms of reserves classification practices, disclosure rules and accounting standards, and a review on the literature on the association between reserves and oil company shareholder returns. Section three describes the methodology and develops the hypotheses. Thereafter, section four describes the data, followed by section five presenting and discussing the empirical results. Section six concludes. 


\section{BACKGROUND AND LITERATURE}

\section{Oil and gas reserves}

The companies' petroleum resources in underground reservoirs cannot fully be counted as an asset. Only the recoverable amounts can be monetized to future cash flows and therefore considered as inventory. The recoverability of reserves is a function of several variables including feasible technology, geology and economics, and is associated with uncertainty. In fact, the Society of Petroleum Engineers (SPE) classifies reserves into several groups according to both the uncertainty and maturity of the recoverable volumes (see Figure 1). 
Figure 1: Society of Petroleum Engineers' oil and gas reserves classification framework

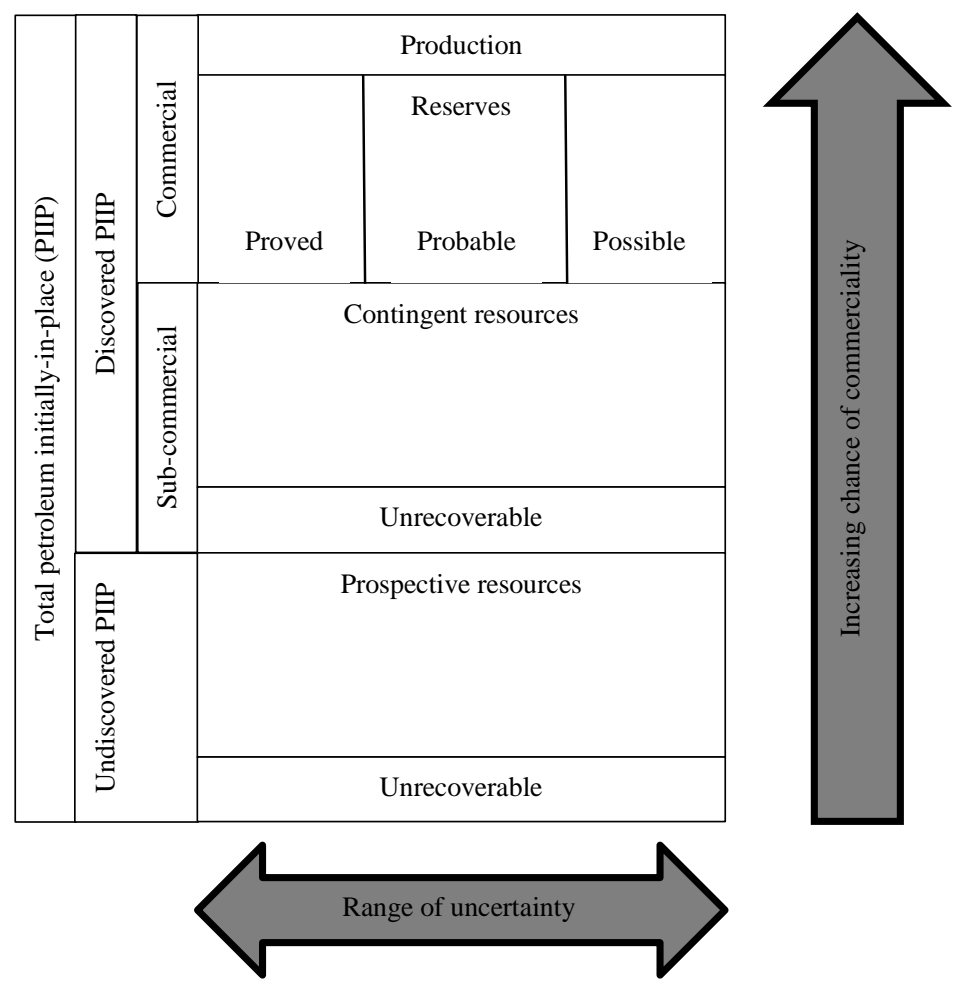

Source: Society of Petroleum Engineers (2011).

The total recoverable volumes are not absolutely certain, but are rather estimates of future production under certain conditions (Mitchell, 2004). These conditions include economic conditions such as commodity prices, knowledge of the projects' ability in development completion and extracting the resources, as well as geological information. These conditions are not always well defined. Since the estimation of reserve amounts cannot be done with complete objectivity, it is possible to arrive at different estimates 
for the same field. An example of this is Shell's $28 \%$ write-down (re-classification) of their proved reserves in 2004.

\section{Disclosure of oil and gas reserves}

While oil companies have calculated their quantities of recoverable reserves for many decades, it was only in the late 1970s and early 1980s that they were actually required to disclose these amounts to the financial markets. The Securities and Exchange Commission (SEC) defined the rules for disclosing oil and gas reserves values in a series of accounting series releases (ASR) (SEC, 1978; 1979 and 1981). In the first two ASR's No. 253 and No. 269, the SEC proposed a new accounting method called Reserve Recognition Accounting (RRA). Unlike previously where the only reserve estimate available in the financial accounts were based on historical incurred cost, the RRA values were based on estimated future cash flows. In 1981, the SEC released ASR No. 289, where it concluded that RRA contained sufficient problems which prevented its use as a potential accounting method for oil and gas producers. Instead, the SEC indicated its support for the work undertaken by the Financial Accounting Standards Board's (FASB) project to develop a comprehensive package of reserves-based disclosures. This project culminated with the FASB Statement of Financial Accounting Standards No. 69 (SFAS No. 69) in 1982 (FASB, 1982), which to this day has sets the overall framework for the disclosure rules for oil and gas companies listed on U.S. stock exchanges. The SFAS No. 69 was later superseded by Accounting Standard Codification (ASC) Topic 132 (FASB, 2009; 2010). The ASC Topic 932 requires oil and gas producers to report several 
supplemental reserves measures. ${ }^{5}$ First, oil and gas producers need to disclose the amounts of reserves they hold across types of products such as oil, gas and nonconventional resources, and across geographical locations. In addition, they need to disclose an estimate of the net present value of their proved reserves at fiscal year-end, called the standardized measure. Finally, they need to separately disclose the change in the standardized measure over the fiscal year. Nevertheless, in terms of types of reserves classes, oil and gas companies are only required to disclose proved reserves. While Topic 932 allows oil and gas producers to disclose probable reserves, most companies do not, and conceal this information from investors. However, under Canadian rules, Canadian oil and gas companies are required to disclose both proved and probable reserves amounts, which allows for analysis into the relationship between different reserves classification and market valuation.

Disclosures of the reserves and reserves amounts are made once a year, usually during the first quarter following the end of the fiscal year. Although this implies that some of the relevant reserves information is only available after the year-end, much of it can already be available to investors. Moreover, many oil companies release quarterly information on production of oil and gas, which for many companies may represent a

\footnotetext{
${ }^{5}$ Early on there were inconsistencies between the 1981 SPE and 1978 SEC definitions. This lead to efforts to align the definitions which culminated in the 1997 SPE reserves definitions for proved, probable and possible categories (Harrell and Gardner, 2005). While 1997 SPE and 1978 SEC proved reserves definitions are very similar, the SEC regulations were generally considered to be more restrictive (see e.g. SPE (2006) for more details). In 2008, the SEC rules were updated and are now consistent with SPE's (SEC, 2008).
} 
substantial part of the total reserves change. Furthermore, due to the sensitivity of stock prices to reserves changes, oil and gas companies promptly announce significant changes to their reserves to the market. Hence, reserves information flows to the market during, and shortly after the end of, the fiscal year. This complicates empirical studies into the relationship between reserves changes and stock market returns. For this reason we have applied contemporaneous returns, i.e. total shareholder return over the fiscal year. Other studies have used lagged returns.

\section{Literature}

Several studies have examined the association between reserves and security returns in the first years following the release of the new regulation in the late 1970s and early 1980s. Some of the earliest studies address the impact of the now discontinued RRA measure and returns (see e.g. Basu and Lynn, 1984; Dharan, 1984; Ghicas and Pastena, 1989; Magliolo, 1986). Other studies address the information content of the supplementary information oil\&gas companies are required to disclose. This strand of the literature examines the relationship between market returns and disclosure of changes in both reserves amounts (Harris and Ohlson, 1987; Spear 1994; Clinch and Magliolo, 1992) and reserves values (Doran, 1988; Doran et al., 1988; Kennedy and Hyon, 1992; Alciatore, 1993; Spear 1996). ${ }^{6}$ However, the results are mixed. Harris and Ohlson (1987) and Doran et al. (1988) found no support for the impact of changes in reserve values on

\footnotetext{
${ }^{6}$ A strand of the literature also examine the value relevance of reserve amounts and net present values, i.e. regression of market values on reserves in levels form (see e.g. Berry et al, 1998; Bryant, 2003; Cormier and Magnan, 2002; Misund et al., 2008).
} 
security returns. Later studies suggest that separation of reserves into its individual components drastically improved the information content of the standardized measure (Alciatore, 1993; Spear, 1996). Furthermore, Boone (2002) argues that the apparent lack of a significant relationship between reserve value changes and security returns can be due to model misspecification (e.g. omitted variable bias).

A few studies have also examined the association of reserve quantities with oil company returns. Clinch and Magliolo (1992) found that changes in reserves due to production dominated all other reserve information. Moreover, Spear (1994) found that the individual components of reserve amounts changes (such as discoveries, production, purchases etc.) improved the relationship with returns. Contrary to Clinch and Magliolo (1992), Spear (1994) and later Cormier and Magnan (2002) find that discoveries are more important than production. In fact, a recent study finds a negative relationship between changes in production and returns (Boyer and Filion, 2007). Furthermore, Osmundsen et al. (2006, 2007) and Quirin et al. (2000) fail to find a significant relationship between market valuation ratios and the reserves replacement ratio, which is calculated as the ratio of new reserve additions divided by production. Hence, the empirical literature has not uncovered a robust relationship between reserves changes and market valuations.

Moreover, perhaps as a result of the focus on proved reserves by the regulators and the accounting standard setters, coupled with the lack of information released by oil 
companies, very few studies have addressed the relevance of different resource classifications. The aim of our paper is provide insight into the impact on less mature reserves on security returns.

\section{METHODOLOGY}

Stock price returns can be affected by a multitude of factors, including profitability and systematic risk factors. In addition, returns may also be influenced by elements specific to the industry to which the companies belong. For instance, oil and gas company returns may be affected by changes in the prices of oil and gas through the impact on revenues, changes in reserves as a result of successful exploration activities, etc. These elements are not directly captured by standard asset pricing models such as the capital asset pricing model (CAPM) (Sharpe, 1964; Lintner, 1965; Mossin, 1966) or multifactor models such as the Fama-French-Carhart four factor model (Fama and French, 1993; 1996; Carhart, 1997). To incorporate company profitability measures, industry specific information or commodity price risk factors, the empirical literature suggest alternative approaches such as the multifactor models such as those applied by Sadorsky (2001) and Boyer and Filion (2007). Our point of departure is Ohlson's (1995) theoretical framework relating market returns to profitability, both current and proxies for future profitability, in addition to the cost of capital. We follow Misund (2015) and use the following empirical representation of the Ohlson model: 


$$
\begin{gathered}
r_{i t}-R F_{t}=\theta_{0}+\alpha_{1} E_{i t} / p_{i t-1}+\alpha_{2} \Delta E_{i t} / p_{i t-1}+\beta_{1} M R P_{t}+\beta_{2} S M B_{t}+ \\
\beta_{3} H M L_{t}+\beta_{4} M O M_{t}+\beta_{5} \Delta O P_{t}+\beta_{6} \Delta G P_{t}+\boldsymbol{\delta o g} \boldsymbol{r}_{i t}+\varepsilon_{i t},
\end{gathered}
$$

where $r_{i t}$ is the total shareholder return for company $i$ at time $t$. The profitability and shocks in profitability from $t-1$ to $t$, are captured by $E_{i t}$ and $\Delta E_{i t}$, respectively. In addition, several risk factors are included. The market risk premium (CAPM) is represented by $M R P_{t}$, while $S M B_{t}$ and $H M L_{t}$ are the returns on the Fama-French (1993; 1996) Small-minus-big and high-minus-low factors, respectively. The Carhart (1997) momentum factor is denoted by $M O M_{t}$. Following Sadorsky (2001), Boyer and Filion (2007), and Misund (2015) we also include a set of commodity risk factors, $\Delta O P_{t}$ and $\Delta G P_{t}$, representing changes in oil and gas prices, respectively. $R F_{t}$ is the risk free rate at time t, and $\varepsilon_{i t}$ is the error term.

The last variable, $\boldsymbol{o g} \boldsymbol{r}$, denotes a vector of oil and gas reserves variables. Ideally, we would like to compare proved to probable and possible reserves. However, we need to select among the types of reserves that are available to investors. Since possible reserves are not disclosed we therefore select the following three types of reserves; proved developed, proved undeveloped and probable reserves. There is a distinction between proved developed and proved undeveloped. The former are reserves which can be extracted from existing wells while the latter are classified as reserves from new wells on undrilled acreage or existing wells where a relatively major expenditure is required for completion. We expect that the market will distinguish between the two types of 
proved reserves, and together with probable reserves the model will provide insight into the relationship between different reserves types and oil company shareholder returns. We propose the following null hypotheses:

$H_{0}^{1}$ : The coefficients on proved developed and proved undeveloped reserves are equal. Formally, this is a F-test of coefficient equality, $\delta_{\text {provdev }}-\delta_{\text {provundev }}=0$. If the null hypothesis is rejected then the results provide evidence that investors value proved developed reserves differently than proved undeveloped reserves.

$H_{0}^{2}$ : The coefficients on proved developed and probable reserves are equal. Formally, this is a F-test of coefficient equality, $\delta_{\text {provdev }}-\delta_{\text {prob }}=0$. If the null hypothesis is rejected then the results provide evidence that investors value proved developed reserves differently than probable reserves.

$H_{0}^{3}$ : The coefficients on proved undeveloped and probable reserves are equal. Formally, this is a F-test of coefficient equality, $\delta_{\text {provundev }}-\delta_{\text {prob }}=0$. If the null hypothesis is rejected then the results provide evidence that investors value proved undeveloped reserves differently than probable reserves.

\section{Impact of the shale gas revolution}


While the previous section addresses the differential impact of oil versus gas reserves on oil company returns, this relationship might not be constant over time. Certain aspects might affect the relationship between changes in reserves and returns. In fact, early studies found a negative effect of investment in exploration activities on security returns. McConnell and Muscarella (1985), Picchi (1985) and Jensen (1986, 1988) examined the impact on valuation of investments in exploration and development (E\&D) activities during a time period characterized by declining commodity prices, excessive spending on E\&D and excessive levels of reserves. The authors all found that the market reacted negatively to E\&D spending. An analogy can be found in recent years. During the late 2000's a structural change in the U.S. natural gas market occured. The US natural gas market has changed dramatically in recent years. The shale-gas boom has increased domestic natural gas production to the degree that only minimal LNG imports might be required to meet domestic demand in the future. After George P. Michell's pioneering work for one and a half decade, the use of hydraulic fracking had a commercial breakthrough in the late 1990s in the Barnet Shale. Devon Energy took this breakthrough further when they combined the use of hydraulic fracking with horizontal drilling in 2003 (Yergin, 2011). This combined development allowed the recovery of shale gas at significantly reduced costs. This has led to an influx of so called unconventional gas on the domestic market. In lack of sufficient export capacity this additional supply has depressed US natural gas prices substantially relative to pre shale-gas levels. The socalled "shale revolution" is commonly dated to around 2009 (see e.g. Oglend et al., 2016), mostly for natural gas, but also for oil at a later stage, and may have impacted on 
the importance of gas reserves. The onset of the shale gas revolution has coincided with a substantial drop in gas prices, while oil prices have increased. ${ }^{7}$ Erdõs (2012), using a vector error correction model, dates the decoupling of oil and gas prices to 2009 , the same year as the onset of the shale gas revolution. Although the Shale gas revolution happened mostly in the U.S., it has also affected the revenue of Canadian oil and gas companies in our sample. Directly, as Canadian oil and gas companies own assets in the U.S shale gas play, and indirectly though the fact that the Canadian and the US markets for natural gas are integrated, see Bachmeier and Griffin (2006). Hence, an interesting research question emerges: has there been a structural shift in the relationship between oil company shareholder returns and gas reserves in 2009? If there has been a differential impact from gas or oil reserve changes on returns, then it is possible to examine this using a structural shift methodology. Following Misund et al. (2008) and Misund (2015), we apply the Gujarati's (1970 a,b) version of the Chow test (Chow, 1960). We include a dummy variable that takes the value 1 for observations in the year 2009 onwards, and 0 otherwise. The dummy variable is interacted with the changes in reserves variables, ogr $\times Y R 2009$, and formally tests for a structural shift by using a Wald test on the coefficients on the interaction terms, both for gas and oil reserves. The hypotheses can be formulated as follows:

\footnotetext{
${ }^{7}$ Academic studies have addressed the divergence of oil and gas prices during this period (see e.g. Asche et al., 2012; Erdõs, 2012).
} 
$H_{0}^{4}$ : No structural shift in the coefficients of the interaction terms between a shale gas dummy variable and gas reserves.

$H_{0}^{5}$ : No structural shift in the coefficients of the interaction terms between shale gas dummy variable and oil reserves.

If we fail to reject $H_{0}^{4}$ and reject $H_{0}^{5}$, this provides evidence that the coefficient on gas reserves has changed, but not that of oil reserves. This will provide evidence that there has been a change in the gas reserves-returns relationship coinciding with the onset of the Shale gas revolution. In order to be able to differentiate between the impacts relating to gas or oil reserves, we do the analysis in two-steps. We estimate Eq. (3) with total reserves disaggregated in to both gas and oil proved developed, proved undeveloped and probable reserves. However, the dummy variable is interacted only with the gas reserves variables in the first step, and only with oil reserves variables in the second step.

\section{DATA}

We collect reserve quantities and reserve values from the financial statements for 94 Canadian oil and gas companies. Earnings are found in the financial statements, while information on reserves is found in the notes of the financial statements. We collect three types of reserves; proved developed, proved undeveloped and probable reserves both oil and gas reserves. The following definitions are taken from Exxon Mobil's 2013 10-K 
filing supplemental information on oil and gas exploration and production activities and SPE (SPE, 2007):

SPE (2007) defines 'Proved oil and gas reserves' as "those quantities of oil and gas, which, by analysis of geoscience and engineering data, can be estimated with reasonable certainty to be economically recoverable, from a given date forward, from known reservoirs, and under current economic conditions, operating methods and government regulations. Proved reserves can be categorized as developed or undeveloped."

Exxon Mobil (2013) defines 'Proved developed reserves' as "those volumes that are expected to be recovered through existing wells with existing equipment and operating methods or in which the cost of the required equipment is relatively minor compared to the cost of a new well."

Exxon Mobil (2013) defines 'Proved undeveloped reserves' as “those volumes that are expected to be recovered from new wells on undrilled acreage, or from existing wells where a relatively major expenditure is required for recompletion."

SPE (2007) defines 'Probable oil and gas reserves' as "those unproven reserves which analysis of geological and engineering data suggests are more likely than not to be recoverable. In this context, when probabilistic methods are used, there should be at 
least a $50 \%$ probability that the quantities actually recovered will equal or exceed the sum of estimated proved plus probable reserves."

Table 1 provides descriptive statistics for the sample.

Table 1: Sample description

\begin{tabular}{|c|c|c|c|c|c|}
\hline Variable & Mean & St.Dev & $\begin{array}{l}25 \\
\text { percentile }\end{array}$ & Median & $\begin{array}{l}75 \\
\text { percentile }\end{array}$ \\
\hline Returns & 0.374 & $\begin{array}{l}1.095 \\
\end{array}$ & -0.132 & 0.158 & 0.548 \\
\hline $\mathrm{E}$ & 0.019 & 0.293 & $<0.001$ & 0.057 & 0.103 \\
\hline$\Delta \mathrm{E}$ & 0.029 & 0.415 & -0.030 & 0.009 & 0.054 \\
\hline Proved developed total res & 0.081 & 0.303 & -0.018 & $<0.001$ & 0.099 \\
\hline Proved developed gas res & 0.252 & 1.202 & -0.062 & $<0.001$ & 0.268 \\
\hline Proved developed oil res & 0.039 & 0.169 & -0.007 & $<0.001$ & 0.035 \\
\hline Proved undeveloped total res & 0.060 & 0.326 & -0.011 & $<0.001$ & 0.070 \\
\hline Proved undeveloped gas res & 0.157 & 0.801 & -0.023 & $<0.001$ & 0.163 \\
\hline Proved undeveloped oil res & 0.031 & 0.217 & -0.002 & $<0.001$ & 0.022 \\
\hline Probable total res & 0.013 & 0.093 & $<0.001$ & $<0.001$ & $<0.001$ \\
\hline Probable gas res & 0.031 & 0.282 & $<0.001$ & $<0.001$ & $<0.001$ \\
\hline Probable oil res & 0.007 & 0.073 & $<0.001$ & $<0.001$ & $<0.001$ \\
\hline MRP & 0.081 & 0.194 & 0.008 & 0.107 & 0.202 \\
\hline SMB & 0.033 & 0.120 & -0.037 & 0.004 & 0.117 \\
\hline HML & 0.025 & 0.161 & -0.080 & 0.037 & 0.132 \\
\hline MOM & 0.056 & 0.242 & 0.032 & 0.086 & 0.178 \\
\hline$\Delta \mathrm{OP}$ & 0.156 & 0.405 & -0.071 & 0.082 & 0.405 \\
\hline
\end{tabular}


$\begin{array}{llllll}\Delta \mathrm{GP} & 0.206 & 0.793 & -0.209 & 0.053 & 0.262\end{array}$

Note: $\mathrm{E}=$ earnings after tax scaled by previous years market value of equity, $\Delta \mathrm{E}=$ change in earnings after tax, scaled by previous years market value of equity, res = reserves measured in oil and gas equivalents. $\mathrm{MRP}=$ market risk premium, SMB and HML are the Fama-French $(1993 ; 1996)$ small-minusbig and high-minus-low risk factors, respectively. MOM is the Carhart (1997) momentum risk factor. $\Delta \mathrm{OP}$ and $\Delta \mathrm{GP}$ are the percentage changes in oil and gas prices, respectively.

We test the models for stationarity using the augmented Dickey-Fuller test (Dickey and Fuller, 1979; Said and Dickey, 1984), heteroskedastiticy using the Breusch-Pagan test (Breusch and Pagan, 1979) and serial correlation using the BreuschGodfrey/Wooldridge test (Breusch, 1978; Godfrey, 1978; Wooldridge, 2002). We reject the null hypotheses of unit roots for all variables for 2 lags (not tabulated), meaning that the data are stationary and need not be first differenced. However, we find the presence of both heteroskedasticity and serial correlation in the error terms in all models. We therefore use the Arellano (1987) method for adjusting the standard errors for both heteroskedasticity and serial correlation in fixed effects models since several of the variables in our models are fixed across the firms in the sample (e.g. oil price and gas prices changes and the Fama-French-Carhart risk factors).

\section{RESULTS AND DISCUSSION}

The impact in shareholder returns of changes in proved developed, proved undeveloped and probable reserves 
In this section we present the results from the empirical model in Eq. (3) and hypotheses 1-3. The results show that several of the variables contribute to explaining the variation in total shareholder returns (Table 2). First of all, we find a significant impact of earnings on returns, but not from changes in earnings. Second, we find that several of the common risk factors are priced by investors, for instance, momentum (MOM), small-minus-big (SMB) and changes in oil and gas prices. Surprisingly, the market risk premium is not priced by investors. Possibly, this might be due to the sample consisting primarily of non-U.S. securities, while the MRP risk factor is calculated from listed U.S. firms. Interestingly, the loading on the MOM factor is significant and negative. This is indicative that mean reversion, and not momentum, explains part of the variation in oil company returns. This is possibly related to the mean reverting nature of commodities such as oil and gas prices (Pindyck, 2003, 2004). Third, we find that changes in proved reserves are positively associated with security returns at the one per cent significance level. This is consistent with prior studies (e.g. Spear, 1996). Moreover, our results suggest that proved undeveloped reserves impact returns, but only at a ten percent level, indicative of a much weaker link to valuation than for proved developed reserves. The coefficients on both proved developed and proved undeveloped are similar, which is also confirmed by the statistical tests on the parameters (Table 3). However, the results also suggest that probable reserves do not impact returns of oil and gas companies. A possible explanation is that investors do not consider that information about this type of reserves conveys information that is useful to forecasting future cash flows. It seems that 
investors primarily use information on proved developed reserves to forecast futures cash flows and secondarily use proved undeveloped reserves.

Table 2. Regression results (with HACSE)

\begin{tabular}{ll}
\hline Variable & Coefficients \\
\hline Intercept & 0.040 \\
$\mathrm{E}$ & $0.277 * *$ \\
$\Delta \mathrm{E}$ & 0.106 \\
Proved developed & $0.435 * * *$ \\
Proved undeveloped & $0.403 *$ \\
Probable & 0.114 \\
MRP & -0.149 \\
SMB & $2.281 * * *$ \\
HML & 0.170 \\
MOM & $-0.677 *$ \\
$\Delta$ OP & $0.732 * * *$ \\
$\Delta$ GP & $0.215 * * *$ \\
Adjusted $\mathrm{R}^{2}$ & 0.294 \\
$F$-statistic & $17.428 * * *$ \\
$\mathrm{~N}$ & 455 \\
\hline
\end{tabular}

Note: $\mathrm{E}=$ earnings after $\overline{\text { tax scaled by previous years market value of equity, }} \Delta \mathrm{E}=$ change in earnings after tax, scaled by previous years market value of equity, res $=$ reserves measured in oil and gas equivalents. $\mathrm{MRP}=$ market risk premium, SMB and HML are the Fama-French $(1993 ; 1996)$ small-minusbig and high-minus-low risk factors, respectively. MOM is the Carhart (1997) momentum risk factor. $\triangle \mathrm{OP}$ and $\Delta \mathrm{GP}$ are the percentage changes in oil and gas prices, respectively. 
Table 3. Hypothesis testing $\left(H_{0}^{1}, H_{0}^{2}\right.$, and $\left.H_{0}^{3}\right)$

\begin{tabular}{lll}
\hline & $\mathrm{F}$ & p-value \\
\hline$H_{0}^{1}:$ DEV = UNDEV & 0.0122 & 0.9122 \\
$H_{0}^{2}:$ DEV = PROB & 1.1223 & 0.2489 \\
$H_{0}^{3}:$ UNDEV = PROB & 0.6657 & 0.4150 \\
\hline
\end{tabular}

Note: DEV, UNDEV and PROB represent the coefficients on changes in developed, undeveloped and probable reserves (total), respectively.

A possible explanation might be related to changes in the relationship between reserves and valuation over time as suggested by prior research (McConnell and Muscarella, 1985; Picchi, 1985; Jensen,1986, 1988; and Spear, 1996). This is addressed in the next section.

\section{Impact of Shale gas revolution}

In the following section we examine the impact of the industry event surrounding the Shale gas revolution. Many commentators have attributed the start of the Shale gas revolution to year 2009, and this date serves as the break point in our analysis. In particular, we examine whether the coefficients on gas reserves have changed after 2009. The results are presented in Table 4 . 
Table 6. Oil vs gas: structural shift due to shale gas

\begin{tabular}{|c|c|c|}
\hline \multirow[b]{2}{*}{ Variable } & \multicolumn{2}{|c|}{ Reserves classification } \\
\hline & Gas & Oil \\
\hline Intercept & 0.044 & 0.033 \\
\hline SHALE & -0.030 & 0.001 \\
\hline $\mathrm{E}$ & $0.235 * * *$ & $0.251 * * *$ \\
\hline$\Delta \mathrm{E}$ & 0.120 & 0.062 \\
\hline GAS DEV & $0.182 * * *$ & -0.038 \\
\hline GAS DEV x SHALE & $-0.339 * * *$ & \\
\hline OIL DEV & $0.675 * * *$ & $0.725 * *$ \\
\hline OIL DEV x SHALE & & -0.186 \\
\hline GAS UNDEV & -0.017 & $-0.133 *$ \\
\hline GAS UNDEV x SHALE & -0.106 & \\
\hline OIL UNDEV & 0.609 & 0.597 \\
\hline OIL UNDEV x SHALE & & 0.339 \\
\hline GAS PROB & -0.025 & 0.271 \\
\hline GAS PROB X SHALE & $0.529 * *$ & \\
\hline OIL PROB & -0.221 & -0.469 \\
\hline OIL PROB X SHALE & & 0.482 \\
\hline MRP & -0.122 & -0.050 \\
\hline SMB & $2.465 * * *$ & $2.353 * * *$ \\
\hline HML & 0.073 & 0.021 \\
\hline MOM & $-0.668 *$ & $-0.710 *$ \\
\hline$\Delta \mathrm{OP}$ & $0.740 * * *$ & $0.686 * * *$ \\
\hline$\Delta \mathrm{GP}$ & $0.215 * * *$ & $0.218 * * *$ \\
\hline
\end{tabular}




\begin{tabular}{lll} 
Adjusted $\mathrm{R}^{2}$ & 0.338 & 0.317 \\
$F$-statistic & $13.223 * * *$ & $11.998 * * *$ \\
Wald $\chi^{2}$ & $11.984 * *$ & 3.082 \\
$\mathrm{~N}$ & 455 & 455 \\
\hline
\end{tabular}

The results suggest that there is both a clear distinction between oil and gas, and before and after 2009 for gas, in terms of impact of changes in reserves on security returns. First of all, in line with the results in the previous section, only changes in proved oil developed reserves impact returns. Moreover, consistent with our expectations, the Shale gas revolution has not impacted the oil reserves-returns relation. However, investors' pricing of gas reserves have changed over the period. Both proved developed and probable gas reserves seem to have experienced a re-pricing. The results indicate that the relationship between returns and changes in proved gas developed reserves has turned from positive to negative after 2009. A possible explanation is that the Shale gas revolution led to a substantial decrease in North American natural gas prices. Hence, the investors might value gas reserves lower than earlier if they believe that the subdued prices will last for a substantial time period. Hence, expected future cash flows from the production of gas reserves have dropped. ${ }^{8}$ A characteristic of Shale gas reserves is that the technology allows a much more rapid development and production than conventional gas plays. This suggests that investors might be of the opinion that the lower cash flows

\footnotetext{
${ }^{8}$ Shale gas economics is also affected by costs, including drilling costs, completion, and productivity (see Ikonnikova et al. (2015)) for a study on shale gas economics and the well level.
} 
come earlier than from other conventional reserves, and hence are discounted less and have a larger impact on shareholder values. This explanation is consistent with findings from studies of oil reserves in the 1980s (McConnell and Muscarella, 1985; Picchi, 1985; Jensen,1986, 1988).

We formally test for a structural shift using Wald $\chi^{2}$ tests. In line with expectations we found a structural shift in the relationship between market returns and changes in gas reserves (reject $H_{0}^{4}$ ), but not for the association with oil reserve changes (can not reject $\left.H_{0}^{5}\right)$. We posited that if we could simultaneously reject $H_{0}^{4}$ but not reject $H_{0}^{5}$, this would provide evidence of that the Shale gas revolution has impacted the relative reservesreturns relationship of gas versus oil reserves. It seems that the Shale gas revolution has impacted how investors value gas reserves.

\section{CONCLUSION}

This paper studies the relationship between total shareholder returns and three types of reserves classifications. Oil companies under U.S. accounting rules and regulation are only required to disclose proved oil and gas reserves. This is also the reason why prior studies examining the impact of reserves on returns have focused on proved reserves. However, as suggested by Osmundsen (2008), the weakness of the proved reserves concept is the exclusion of more immature reserves. In fact, the Society of Petroleum Engineers classifies oil and gas reserve according to probability of recoverability from petroleum reservoirs. Hence, this information can provide information for investors 
wanting to forecast future cash flows. However, since oil companies are not required to disclose it, the information is not readily available for investors. However, in some countries outside the U.S., disclosure of other reserves classifications is mandatory. Using a sample of firms, mainly Canadian, which disclose information on immature reserves, we address three issues. First, we examine if other reserves classifications other than proved developed reserves are valuation relevant. Second, we test if gas and oil reserves are valued differently across reserves classifications. Last, we test whether the impact of an industry event with wide ranging effects has impacted the reserves-returns relationship differently for oil and gas reserves, and across the three reserves classifications.

Our results suggest that proved developed reserves are the main type of reserves used by investors to forecast future cash flows. However, we do find that there is a difference between oil and gas reserves, and especially after 2009, coinciding with the Shale gas revolution. The effect can be explained by the impact of Shale gas on the natural gas prices in North America.

Our results can also be relevant for understanding the recent Shale oil boom and the how it may have affected the valuation of oil and gas companies. 


\section{ACKNOWLEDGEMENT}

We thank J.S. Herold (IHS Herold) for generously providing us with data for this study.

\section{REFERENCES}

Adelman, M.A. and G.C. Watkins (2008). Reserve Prices and Mineral Resource Theory. The Energy Journal, 29 (Special Issue), 1-16.

Alciatore, M.L. 1993. New Evidence on SFAS No. 69 and the Components of the Change in Reserve Value. The Accounting Review 68(3), 639-656

Arellano, M. (1987). Computing Robust Standard Errors for Within-groups Estimators. Oxford Bulletin of Economics and Statistics, 49 (4), 431-434.

Asche, F., Oglend, A. and P. Osmundsen (2012). Gas versus Oil Prices the Impact of Shale Gas. Energy Policy 47, 117-124.

Bachmeier, L.J. and J.M. Griffin (2006), “Testing for market integration crude oil, coal, and natural gas", The Energy Journal 27, 55-71.

Basu, S. and B.E. Lynn (1984). Discounted Cash-Flow Requirements in the Oil and Gas Industry. Cost \& Management, (November-December), 15-25.

Berry, K.T., Hasan, T. and D. O'Bryan (1998). Relative Information Content of Proved Reserves: The BOEs-Revenue vs BOEs-Energy. Journal of Energy Finance and Development 3 (1), 1-11. 
Boone, J. (2002). Revisiting the Reportedly Weak Value Relevance of Oil and Gas Asset Present Values: The Roles of Measurement Error, Model Misspecification, and Time-Period Idiosyncrasy. The Accounting Review 77 (1), 73-106.

Boyer, M.M. and D. Filion (2007). Common and fundamental factors in stock returns of Canadian oil and gas companies. Energy Economics 29, 428-453.

Breusch, T.S. (1978). Testing for Autocorrelation in Dynamic Linear Models. Australian Economic Papers 17, 334-355.

Breusch, T.S. and A.R. Pagan (1979). A Simple Test for Heteroskedasticity and Random Coefficient Variation. Econometrica 47 (5), 1287-1294.

Bryant, L. (2003). Relative Value Relevance of the Success Efforts and Full Cost Accounting Methods in the Oil and Gas Industry. Review of Accounting Studies $8(1), 5-28$.

Canadian Securities Administrators (2002a). National Instrument 51-101: Standards of Disclosure for Oil and Gas Activities. CSA: Alberta.

Canadian Securities Administrators (2002b). Companion Policy 51-101: Standards of Disclosure for Oil and Gas Activities. CSA: Alberta.

Carhart, M.M. (1997). On Persistence in Mutual Fund Performance. The Journal of Finance 52 (1), 57-82.

Chow, G.C. (1960). Tests of Equality Between Sets of Coefficients in Two Linear Regressions. Econometrica 28 (3), 591-605.

Clinch, G. and J. Magliolo (1992). Market Perceptions of Reserve Disclosures under SFAS no. 69. The Accounting Review 67 (October), 843-861. 
Cormier, D. and M. Magnan (2002). Performance Reporting by Oil and Gas Firms: Contractual and Value Implications. Journal of International Accounting, Auditing and Taxation 11 (2), 131-153.

Dharan, B.G. (1984). Expectation Models and Potential Information Content of Oil and Gas Reserve Disclosures. The Accounting Review 59 (2),199-217.

Dickey, D.A. and W.A. Fuller (1979). Distribution of the Estimators for Autoregressive Time Series with a Unit Root. Journal of the American Statistical Association 74 (366), 427-431.

Doran, B.M., Collins, D. and D. Dhaliwal (1988). The Information of Historical Cost Earnings Relative to Supplemental Reserve-Based Accounting Data in the Extractive Petroleum Industry. The Accounting Review, 63 (3), 389-413

Erdõs, P. (2012). Have Oil and Gas Prices Got Separated? Energy Policy 49, 707-718.

Fama, E.F. and K.R. French (1993). Common Risk Factors in the Returns on Stocks and Bonds. Journal of Financial Economics 33 (1), 3-56.

Fama, E.F. and K.R. French (1996). Multifactor Explanations of Asset Anomalies. The Journal of Finance 51 (1), 55-84.

Financial Accounting Standards Board (1982). Statement of Financial Accounting Standards No. 69: Disclosures about Oil and Gas Producing Activities. FASB: Stamford, CT.

Financial Accounting Standards Board (2009). Financial Accounting Codification Topic 932: Extractive Activities - Oil and Gas. FASB: Stamford, CT. 
Financial Accounting Standards Board (2010). Financial Accounting Series. Accounting Standards Update. Extractive Activities - Oil and Gas (Topic 932): Oil and Gas Reserves Estimation and Disclosures. An Amendment of the FAB Accounting Standards Codification. FASB: Stamford, CT.

Ghicas, D. and V. Pastena (1989). The Acquisition Value of Oil and Gas Firms: The Role of Historical Costs, Reserve Recognition Accounting, and Analysts' Appraisals. Contemporary Accounting Research 6 (1), 125-142.

Godfrey, L.G. (1978). Testing Against General Autoregressive and Moving Average Error Models when the Regressors Include Lagged Dependent Variables. Econometrica 46 (6), 1293-1302.

Gujarati, D. (1970a). Use of Dummy Variables in Testing for Equality Between Sets of Coefficients in Two Linear Regression: A Note. American Statistician 24 (1), $50-52$.

Gujarati, D. (1970b). Use of Dummy Variables in Testing for Equality Between Sets of Coefficients in Two Linear Regression: A Generalization. American Statistician $24(5), 18-21$.

Harrell, D.R. and T.L. Gartner (2005). Significant differences in proved reserves estimates using SPE/WPC definitions compared to United States Securities and Exchange Commission definitions. SPE Reservoir Evaluation \& Engineering, December, 520-527.

Harris, T.S. and J.A. Ohlson (1987). Accounting Disclosures and the Market's Valuation of Oil and Gas Properties. The Accounting Review 62 (4), 651-670. 
Ikonnikova, S., Gülen, G, Browning, J. And S.W. Tinker. (2015). Profitability of shale gas drilling: A case study of the Fayetteville shale play. Energy 81, 382-393.

International Accounting Standards Board (2004). International Financial Reporting Standard 6: Exploration for and Evaluation of Mineral Resources. IASB: London.

Jegadeesh, N. and S. Titman (1993). Returns to Buying Winners and Selling Losers: Implications for Stock Market Efficiency. The Journal of Finance 48 (1), 65-91.

Jensen, M.C. (1986). Agency Costs of Free Cash Flow, Corporate Finance and Takeovers. The American Economic Review 76 (2), 323-329.

Jensen, M.C. (1988). The Takeover Controversy: Analysis and Evidence. In Knights, Raiders and Targets: The Impact of the Hostile Takeover, J. Coffee, L. Lowenstein and S. Rose-Ackerman (eds.). Oxford University Press: Oxford.

Kennedy, D. and Y. Hyon (1992). Do RRA Earnings Improve the Usefulness of Reported Earnings in Reflecting the Performance of Oil and Gas Producing Firms. Journal of Accounting, Auditing and Finance 7, 335-360.

Kretzschmar, G.L., Misund, B. And D. Hatherly (2007). Market Risks and Oilfield Ownership - Refining Oil and Gas Disclosures. Energy Policy, 35 (11), 59095917.

Lintner, J. (1965). The Valuation of Risk Assets and the Selection of Risky Investments in Stock Portfolios and Capital Budgets. Review of Economics and Statistics 47(1), 13-37. 
Magliolo, J. (1986). Capital Market Analysis of Reserve Recognition Accounting. Journal of Accounting Research 24 (Supplement), 69-108.

McConnell, J and C. Muscarella (1985). Corporate Capital Expenditure Decisions and the Market Value of the Firm. Journal of Financial Economics 14 (3), 399-422.

Misund, B., F. Asche and P. Osmundsen (2008). Industry Upheaval and Valuation: Empirical Evidence from the International Oil and Gas Industry. The International Journal of Accounting 43 (4), 398-424.

Mitchell, J. (2004). Petroleum Reserves in Question. Oxford: Oxford Institute for Energy Studies.

Mossin, J. (1966). Equilibrium in a Capital Asset Market. Econometrica 34(4), 768-783.

Oglend, A., Lindbäck, M. and P. Osmundsen (2016). Shale Gas Boom Affecting the Relationship Between LPG and Oil Prices. The Energy Journal 37 (1), 211-232.

Ohlson, J.A. (1995). Earnings, Book Values, and Dividends in Equity Valuation. Contemporary Accounting Research 11 (2), 661-687.

Osmundsen, K. Mohn, Misund, B. and F. Asche (2007). Is Oil Supply Choked by Financial Market Pressures? Energy Policy 35 (1), 467-474.

Osmundsen, P, Asche, F., Misund, B. and K. Mohn (2006). Valuation of International Oil Companies. The Energy Journal 27 (3), 49-64.

Osmundsen, P. (2010). Chasing Reserves - Incentives and Ownership in Bjørndal, E., Bjørndal, M., Pardalos, P.M. and M. Rönnqvist, eds. (2010), Energy, Natural Resource and Environmental Economics. Heidelberg: Springer-Verlag, 19-39. 
Picchi, B. (1985). Structure of the U.S. Oil Industry: Past and Future. Salomon Brothers (July).

Quirin, J.J., Berry, K.T. and D. O’Bryan (2000). A fundamental analysis approach to oil and gas firm valuation. Journal of Business Finance \& Accounting 27(7\&8), 785-820.

Sadorsky, P. (2001). Risk factors in stock returns of Canadian oil and gas companies. Energy Economics 23, 17-28.

Scholtens, B. and R. Wagenaar (2011). Revisions of international firms' energy reserves and the reaction of the stock market. Energy 36(5), 3541-3546.

Securities and Exchange Commission (1978). Accounting Series Release NO. 253. SEC: Washington, D.C.

Securities and Exchange Commission (1979). Accounting Series Release NO. 269: Oil and gas producers - supplemental disclosures on the basis of reserve recognition accounting. SEC: Washington, D.C.

Securities and Exchange Commission (1981). Accounting Series Release NO. 289. SEC: Washington, D.C.

Securities and Exchange Commission (1982). Financial reporting release No. 9: Supplemental disclosures of oil and gas producing activities. SEC: Washington, D.C.

Securities and Exchange Commission (2008). Modernization of Oil and Gas Reporting Requirements: The Final Rule. SEC: Washington 
Sharpe, W.F. (1964). Capital Asset Prices: A Theory of Market Equilibrium Under Conditions of Risk. The Journal of Finance 19 (3), 425-442.

Society of Petroleum Engineers (1965). Definitions of Proved Reserves for Property Evaluation. SPE: Richardson, TX.

Society of Petroleum Engineers (1981). Updated Proved Oil and Gas Definitions. SPE: Richardson, TX.

Society of Petroleum Engineers (1997). Petroleum Reserves Definitions. SPE: Richardson, TX.

Society of Petroleum Engineers (1997). SPE: Richardson, TX.

Society of Petroleum Engineers (2011). Guidelines for Application of the Petroleum Management System, November 2011. http://www.spe.org/industry/docs/PRMS_Guidelines_Nov2011.pdf:_SPE: Richardson, TX.

Spear, N.A. (1994). The Stock Market Reaction to the Reserve Quantity Disclosures of U.S. Oil and Gas producers. Contemporary Accounting Research 11(1), 381-404. Spear, N.A. (1996). The Stock Market Reaction to the Reserve-Based Value Replacement Measures of Oil and Gas Producers. Journal of Business, Finance and Accounting 23(7), 953-974.

Teall, H.D. (1992). Information Content of Canadian Oil and Gas Companies' Historic Cost Earnings and Reserves Disclosures. Contemporary Accounting Research 8 (2), 561-579. 
White, H. (1980). A heteroskedasticity-consistent covariance matrix estimator and a direct test from heteroskedastcity. Econometrica, 40(May), 817-838.

Wooldridge, J.M. (2002). Econometric Analysis of Cross-Section and Panel Data. MIT Press.

Yergin, D. (2011). Stepping on the gas. The Wall Street Journal, April 2, the Saturday essay. 